\title{
PENGEMBANGAN PETUNJUK PRAKTIKUM BIOLOGI BERBASIS PENDEKATAN ILMIAH (SCIENTIFIC APPROACH) UNTUK SISWA SMA KELAS XI SEMESTER GENAP TAHUN PELAJARAN 2013/2014
}

\author{
Winda Budiarti ${ }^{1}$ \\ Anak Agung Oka ${ }^{2}$ \\ ${ }^{1,2}$ Pendidikan Biologi FKIP Universitas Muhammadiyah Metro \\ E-mail: winda.alzena@yahoo.co.id
}

\begin{abstract}
This research aims to develop a biology practical guidance based on the scientific approach for senior high schools at the eleventh grades students. There are three stages of development was conducted in developing practical guidance based on the scientific approach, it is defining, planning, and development. This instructions lab-based on the scientific approach is tested for feasibility by the experts and got an average score of $86.49 \%$ in the excellent category. Besides practical guidance based on the scientific approach was also tested to the students in public and private schools. The students test in public schools get an average of $87.11 \%$ in the excellent category and in private schools get an average of $85.71 \%$ in the excellent category. Hopefully the teachers and the students utilizing a biology practical guidance on the scientific approach as a guide that can helps in the lab activities
\end{abstract}

Kata Kunci: petunjuk praktikum, pendekatan ilmiah (scientific approach)

Pendidikan merupakan suatu proses dalam rangka mempengaruhi siswa untuk menyesuaikan diri sebaik mungkin dengan lingkungannya, sehingga akan menimbulkan perubahan dalam diri siswa yang memungkinkan untuk bisa berfungsi dalam kehidupan masyarakat. Dalam pengelolaan pendidikan tentu tidaklah sederhana, banyak sekali masalah dan kendala yang dihadapi. Salah satu masalah pendidikan yang dihadapi bangsa Indonesia adalah rendahnya mutu pendidikan. Pemerintah berusaha memperbaiki mutu pendidikan melalui pengembangan sistem pendidikan, di antaranya adalah dilakukan perubahan Kurikulum pendidikan Nasional setiap kurun waktu tertentu. Perubahan ini diharapkan dapat mewujudkan tujuan pendidikan Nasional yaitu terbentuknya manusia Indonesia yang memiliki kecerdasan intelektual dan keterampian yang diperlukan untuk dirinya, masyarakat, bangsa dan negara. Berdasarkan tujuan tersebut maka baru-baru ini pemerintah menerbitkan Kurikulum baru (Kurikulum 2013) sebagai upaya memperbaiki dan mengembangkan Kurikulum sebelumnya.

Permendikbud Nomor 65 Tahun 2013 menjelaskan bahwa salah satu poin penting dalam Kurikulum 2013 adalah di mana menekankan sasaran pembelajaran yang mencakup pengembangan ranah sikap, pengetahuan, dan keterampilan yang dielaborasi untuk setiap satuan pendidikan. Untuk memperkuat pendekatan ilmiah (scientific approach), tematik terpadu (tematik antar mata pelajaran), dan tematik (dalam suatu mata pelajaran) perlu diterapkan 
pembelajaran berbasis penyingkapan dan penelitian. Salah satu pelajaran yang cocok menggunakan pendekatan ilmiah (scientific approach) adalah mata pelajaran biologi. Karakteristik biologi sebagai ilmu mempunyai objek kajian berupa benda konkret dan dapat ditangkap indera dikembangkan berdasarkan pengalaman empiris (pengalaman nyata). Pengalaman empiris salah satunya dapat dilakukan melalui kegiatan praktikum. Kegiatan praktikum yang dilakukan tidak hanya berorientasi pada hasil akhir yang akan diperoleh, tetapi melibatkan bagaimana proses untuk menemukan fakta sains. Proses praktikum membutuhkan suatu penuntun berupa petunjuk praktikum yang digunakan untuk memandu siswa melakukan praktikum. Petunjuk praktikum yang baik dibuat berdasarkan karakteristik pendekaatan ilmiah (scientific approach) dengan menerapkan prinsip metode ilmiah sesuai dengan Kurikulum 2013. Hasil pra survei yang telah dilakukan diperoleh bahwa dalam kegiatan praktikum boilogi petunjuk praktikum yang digunakan masih sederhana dan memiliki banyak kelemahan di antaranya adalah dari segi kelengkapan komponennya, petunjuk praktikum yang tersedia masih sangat sederhana atau belum lengkap (hanya berupa judul, tujuan, alat bahan, dan cara kerja), dari segi filosofi, petunjuk praktikum yang ada belum mencerminkan alat yang bisa membantu siswa untuk berfikir ilmiah, seperti tidak ada pertanyaan penelitian (rumusan masalah), dasar teori dan hipotesis (penalaran ilmiah) dan membuat kesimpulan dengan diskusi kelompok (membentuk jejaring), dan belum dibukukan satu semester.
Permasalahan inilah yang menjadi faktor penting bagi penulis untuk mengembangkan sebuah petunjuk praktikum biologi berdasarkan komponen-komponen petunjuk praktikum yang lengkap, isinya menggunakan pendekatan ilmiah (scientific approach) sesuai Kurikulum 2013 dan terdiri dari berbagai materi pokok agar dapat digunakan oleh siswa SMA yang dibukukan, sehingga diharapkan dapat mempermudah siswa dalam pelaksanaan praktikum dan dapat membuat siswa mampu mencapai tujuan pembelajaran sesuai harapan Kurikulum 2013.

Metode praktikum adalah suatu cara penyajian pembelajaran yang menuntut siswa secara aktif mengalami dan membuktikan sendiri tentang apa yang dipelajarinya. Metode praktikum menitik beratkan pada kegiatan untuk melakukan pengamatan, percobaan, pengumpulan data yang dilakukan di laboratorium atau tempat lain yang disamakan dengan laboratorium, melakukan pembahasan dan pelaporan sehingga siswa mengalami dan membuktikan sendiri sesuatu yang dipelajari, Winatapura (dalam Purnamasari, 2012:10)

$$
\text { Sulistyowati }
$$

(dalam

Farikhayati, 2009:14) 'Kerja praktik di laboratorium mempunyai peran ganda, yaitu pengalaman kerja nyata dan merangsang peserta didik agar berlatih berpikir dengan cara-cara kritis dan ilmiah".

Petunjuk praktikum adalah "pedoman pelaksanaan praktikum yang berisi tata cara persiapan, pelaksanaan, analisis data, dan pelaporan"(Purnamasari,2012).

Untuk mempermudah pemahaman peserta didik, hendaknya peserta didik diberi buku petunjuk praktikum yang di 
dalamnya sudah tercantum hal-hal yang berkaitan dengan praktikum, seperti judul-judul percobaan yang akan dilakukan, prosedur kerja atau langkah-langkah kerja, lembar pengamatan, serta pertanyaanpertanyaan guna mengungkap pengetahuan peserta didik setelah berpraktikum (Farikhayati, 2009:14).

Kurikulum 2013 menekankan

pada dimensi pedagogik modern dalam pembelajaran yaitu menggunakan pendekatan ilmiah. Pendekatan ilmiah (scientific approach) dalam pembelajaran sebagaimana dimaksud meliputi mengamati, menanya, menalar, mencoba, dan membentuk jejaring untuk semua mata pelajaran (Kemdikbud, 2013).

Menurut Santrock (2003) pendekatan ilmiah (scientific approach) adalah suatu pendekatan yang dapat digunakan untuk menemukan informasi yang tepat tentang tingkah laku dan perkembangan, pendekatan ilmiah mencakup langkah-langkah yaitu, identifikasi dan analisis masalah, pengumpulan data, menarik kesimpulan, dan merevisi teori.

"Pendekatan ilmiah (scientific approach) sebagai pendekatan dalam memecahkan masalah, yang secara umum mencakup komponen-komponen observasi, hipotesis, eksperimen, dan teori" (Tim pengembang ilmu pendidikan FIP-UPI, 2007)

\section{METODE}

\section{A. Prosedur Pengembangan}

Penelitian ini menggunakan prosedur penelitian dan model pengembangan perangkat 4D (Four$D$ Model) yang disarankan oleh Thiagarajan, Semmel, dan Semmel (dalam Trianto, 2011:93). Model ini terdiri dari 4 tahap pengembangan, yaitu Define, Design, Develop, and Desseminate atau diadaptasi menjadi model 4-P, yaitu pendefinisian, perancangan, pengembangan, dan penyebaran. Namun pada penelitian dan pengembangan ini, kegiatan yang dilakukan hanya sampai pada tahap pengembangan.

\section{a. Tahap Pendefinisian (Define)}

1. Studi lapangan

Studi lapangan dilakukan untuk mengumpulkan informasi yang berkenaan dengan fasilitas pendukung kegiatan praktikum meliputi petunjuk praktikum, laboratorium biologi (ruangan yang dapat digunakan untuk praktikum), ketersediaan alat dan bahan.

2. Studi Literatur

Studi literatur dilakukan untuk mengalisis Kurikulum 2013 yang meliputi analisis terhadap Standar Isi mata pelajaran biologi, yaitu Kompetensi Inti (KI) atau Kompetensi Dasar (KD), materi pokok yang dipilih dalam penelitian ini adalah materi kelas XI semester genap, untuk menentukan kualitas petunjuk praktikum yang akan dibuat ini berdasarkan berbagai referensi dari buku maupun dari internet.

\section{b. Tahap Perancangan (Design)}

Pada tahap perancangan yaitu membuat draf awal petunjuk praktikum, dilakukan perancangan komponen-komponen petunjuk praktikum biologi yang meliputi teks dan gambar terkait kegiatan praktikum untuk melatih keterampilan siswa. Termasuk di dalamnya pertanyaan-pertanyaan yang harus dikerjakan siswa yang mengarahkan mereka untuk menemukan konsep penting terkait 
materi ajar. Produk akhir tahap ini adalah tersedianya teks dan gambar petunjuk praktikum biologi yang siap diproses pada tahap selanjutnya.

\section{c. Tahap Penge mbangan (Develop)}

Pada tahap ini adalah membuat petunjuk praktikum biologi. Setelah petunjuk praktikum jadi selanjutnya dilakukan langkah:

a) Uji validasi produk petunjuk praktikum biologi yang pertama kali dibuat akan di validasi oleh ahli yaitu dosen dan guru SMA mengenai kelayakan petunjuk praktikum. Hasil validasi produk akan direvisi dan digunakan sebagai bahan pertimbangan untuk menyempurnakan petunjuk praktikum biologi yang layak digunakan.

b) Uji coba siswa, petunjuk praktikum biologi yang sudah divalidasi selanjutnya akan diuji coba kepada siswa kelas XI IPA dengan tujuan mengetahui apakah petunjuk praktikum bisa digunakan dalam kegiatan praktikum dan bagaimana tanggapan/respon siswa terhadap petunjuk praktikum biologi.

\section{B. Analisis Data}

Setelah data diperoleh, selanjutnya adalah menganalisis data tersebut. Penelitian ini lebih menitik beratkan pada bagaimana mengembangkan petunjuk praktikum biologi SMA, sehingga data hasil angket dilakukan langkah-langkah sebagai berikut:

1. Mengkuantitatifkan hasil angket sesuai dengan indikator yang telah ditetapkan dengan memberikan skor sesuai dengan bobot yang telah ditentukan sebelumnya

2. Membuat tabulasi data

3. Menghitung persentase dari tiaptiap sub variabel dengan rumus:
Dimana:

$$
P(s)=\frac{s}{N} \times 100 \%
$$

$\mathrm{P}(\mathrm{s})=$ Persentase Sub Variabel

$\mathrm{S}=$ Jumlah sekor tiap sub variabel

$\mathrm{N}=$ Jumlah sekor maxsimum

(Ali dalam Kristiningrum, 2007:52)

4. Dari persentase yang telah diperoleh kemudian ditransformasikan ke dalam tabel supaya pembacaan hasil penelitian menjadi mudah. Untuk menentukan kriteria kualitatif dilakukan dengan cara:

a. Menentukan persentase skor ideal (skor maksimum) = $100 \%$.

b. Menentukan persentase skor terendah (skor minimum) $=$ $0 \%$.

c. Menentukan range $=100-0=$ 100.

d. Menentukan interval yang dikehendaki $=5$ (sangat baik, baik, cukup baik, tidak baik, dan sangat tidak baik).

e. Menentukan lebar interval $(100 / 5=20)$.

Berdasarkan perhitungan di atas, maka range persentase dan kriteria kualitatif dapat dilihat pada Tabel 2.

Tabel 2. Range Persentase dan Kriteria Kualitatif Petunjuk Praktikum

\begin{tabular}{l|l|l}
\hline NO & Interval & Kriteria \\
\hline 1 & $\begin{array}{l}81 \% \leq \text { skor } \leq \\
100 \%\end{array}$ & Sangat Baik \\
\hline 2 & $\begin{array}{l}61 \% \leq \text { skor } \leq \\
80 \%\end{array}$ & Baik \\
\hline 3 & $\begin{array}{l}41 \% \leq \text { skor } \leq \\
60 \%\end{array}$ & Cukup baik \\
\hline 4 & $\begin{array}{l}21 \% \leq \text { skor } \leq \\
40 \%\end{array}$ & Tidak Baik \\
\hline
\end{tabular}




\begin{tabular}{l|l|l}
\hline 5 & $0 \% \leq$ skor $\leq 20 \%$ & $\begin{array}{l}\text { Sangat } \\
\text { Tidak baik }\end{array}$ \\
\hline
\end{tabular}

Sumber: (Ali dalam Kristiningrum, 2007:52)

Penelitian ini dikatakan berhasil apabila dari angket diperoleh hasil yang berada pada rentang $81 \% \leq$ skor $\leq$ $100 \%$, dan $61 \% \leq$ skor $\leq 80 \%$ atau pada kriteria "Sangat Baik",dan "Baik".

\section{HASIL}

\section{A. Hasil Pembuatan Petunjuk Praktikum Biologi Berbasis Pendekatan Ilmiah (Scientific Approach)}

Hasil kajian studi literatur dan studi lapangan dijadikan dasar dalam pembuatan petunjuk praktikum. Pembuatan petunjuk praktikum dilakukan dengan beberapa tahap, yaitu:

1. Tahap pertama, adalah menentukan topik praktikum yang dibuat pada petunjuk praktikum. Hasil dari analisis materi dan wawancara dengan guru-guru biologi SMA, topik praktikum yang dibuat ada enam topik yaitu, uji kandungan nutrisi pada makanan, mengukur pernapasan paru-paru, mengamati pernapasan pada hewan, menguji kandungan urin, gerak refleks, dan pencangkokan pada tumbuhan.

2. Tahap kedua, adalah mengumpulkan sumber-sumber pustaka atau referensi yang relevan untuk kegiatan praktikum pada tingkat SMA, seperti materi biologi kelas XI IPA semester genap.

3. Tahap ketiga, adalah mengumpulkan gambar-gambar yang terkait dalam kegiatan praktikum.
4. Tahap keempat, adalah menyusun kerangka awal petunjuk praktikum.

5. Tahap kelima, adalah penulisan dan pengetikan petunjuk praktikum. Sesuai kerangka awal petunjuk praktikum.

\section{B. Pengujian Petunjuk Praktikum Biologi Berbasis Pendekatan Ilmiah (Scientific Approach)}

\section{Uji Kelayakan Petunjuk Praktikum Oleh Ahli}

Pengujian petunjuk praktikum dilakukan dengan meminta ahli membaca petunjuk praktikum kemudian mendata tanggapan ahli mengenai isi dari petunjuk praktikum biologi kelas XI semester genap dan tampilannya. Ada tiga kriteria kelayakan petunjuk praktikum yang diuji oleh ahli. Ketiga kriteria tersebut yaitu aspek materi, aspek tampilan produk, dan aspek interpretasi pendekatan ilmiah (scientific approach). Pengujian petunjuk praktikum dilakukan oleh tiga orang ahli yaitu satu dosen biologi dan dua guru SMA.

1) Hasil penilaian ahli untuk aspek materi

Dari hasil pengujian menunjukkan semua indikator mendapatkan nilai sangat baik, dengan nilai persentase variabel materi petunjuk praktikum berbasis pendekatan ilmiah (scientific approach) sebesar 86,18 tergolong dalam kategori sangat baik.

2) Hasil penilaian ahli untuk aspek tampilan

Dari hasil pengujian menunjukkan bahwa rata-rata indikator mendapatkan nilai sangat baik, dengan nilai persentase variabel tampilan produk petunjuk praktikum 
berbasis pendekatan ilmiah (scientific approach) sebesar 87,99 tergolong dalam kategori sangat baik.

3) Hasil penilaian ahli untuk aspek interpretasi pendekatan ilmiah (Scientific Approach)

Dari hasil pengujian menunjukkan bahwa rata-rata indikator mendapatkan nilai sangat baik, dengan nilai persentase variabel tampilan produk petunjuk praktikum berbasis pendekatan ilmiah (scientific approach) sebesar 85,32 tergolong dalam kategori sangat baik.

Berdasarkan hasil analisis angket dari para ahli baik dosen dan guru mengenai petunjuk praktikum yang dikembangkan menghasilkan persentase rata-rata sebesar: $86,18 \%+87,99 \%+85,32 \%$

$$
3
$$

Hasil 86,49\% tergolong dalam ketegori sangat baik. Dengan demikian dapat disimpulkan bahwa dari segi materi, tampilan, dan interpretasinya pada pendeketan ilmiah petunjuk praktikum yang dikembangkan layak untuk dijadikan sebagai penuntun dalam kegiatan praktikum.

\section{Hasil Uji Lapangan}

\section{1) Hasil Tanggapan/Respon Sis wa SMA N 6 Metro}

Untuk skor persentase rata-rata hasil angket tanggapan/respon siswa di SMA N 6 Metro adalah:

$\frac{\begin{array}{l}\text { Jumlah } \\ 88,95 \%+86,25 \%+86,15 \%\end{array}}{3}=87,11 \%$

Berdasarkan hasil analisis angket tanggapan/respon siswa di SMA N 6 Metro mengenai petunjuk praktikum yang dikembangkan menghasilkan persentase sebesar $87,11 \%$ tergolong dalam kategori sangat baik. Dengan demikian, dapat disimpulkan bahwa petunjuk praktikum yang dikembangkan mencapai kelayakan. Sehingga petunjuk praktikum berbasis pendekatan ilmiah (scientific approach) layak untuk dijadikan penuntun dalam kegiatan praktikum.

\section{2) Hasil Tanggapan/Respon Sis wa SMA Muhammadiyah 1 Metro}

Untuk skor persentase rata-rata hasil angket tanggapan/respon siswa di SMA Muhammadiyah 1 Metro adalah:

$\begin{aligned} & \text { Jumlah } \\ & 85,5 \%+86,35 \%+85,3 \%\end{aligned}=85,71 \%$
3

Berdasarkan hasil analisis angket tanggapan/respon siswa di SMA Muhammadiyah 1 Metro mengenai petunjuk praktikum yang dikembangkan menghasilkan persentase sebesar $85,71 \%$ tergolong dalam kategori sangat baik. Dengan demikian, dapat disimpulkan bahwa petunjuk praktikum yang dikembangkan mencapai kelayakan. Sehingga petunjuk praktikum berbasis pendekatan ilmiah (scientific approach) layak untuk dijadikan penuntun dalam kegiatan praktikum.

\section{Revisi}

Hal-hal yang telah direvisi dari saran ahli dijelaskan sebagai berikut:

1. Memperbaiki sampul petunjuk praktikum yang sebelumnya gambarnya organ pencernaan, pernapasan, dan eskresi diubah menjadi gambar sesuai topik praktikum dan menuliskan topik praktikum pada sampul. 
2. Mengubah jenis (font) huruf yang mulanya Times New Roman menjadi Arial.

3. Menambahkan sumber belajar tambahan atau referensi tambahan yang mulanya tidak ada.

4. Memperbesar gambar alat.

5. Membuat cara kerja lebih spesifik yang mulanya umum.

6. Memberikan tanda seru pada kalimat perintah.

7. Memperbaiki tampilan petunjuk praktikum dengan mengurangi warna dan aksesoris gambar, serta memperbaiki tampilan yang belum pas sesuai saran ahli.

\section{PEMBAHASAN}

Tahap pertama yaitu tahap pendefinisian dimana ada dua hal yang telah dilakukan pada tahap ini meliputi studi lapangan dan studi literatur. Studi lapangan dilakukan untuk mencari informasi berkaitan dengan kegiatan praktikum di sekolah serta keadaan petunjuk praktikum yang ada di sekolah, sedangkan studi literatur dilakukan dengan mempelajari standar isi yaitu Kompetensi Inti dan Kompetensi Dasar berdasarkan Kurikulum 2013 dan mempelajari komponenkomponen yang harus ada dalam petunjuk praktikum serta mempelajari komponen dalam pendekatan ilmiah.

Tahap yang kedua adalah perancangan petunjuk praktikum berbasis pendekatan ilmiah (scientific approach). Dalam merancang petunjuk praktikum ada beberapa hal yang telah dilakukan mulai dari memilih topik dari meteri pokok yang akan dibuat percobaan, merancang komponen-komponen yang ada dalam petunjuk praktikum serta mengumpulkan teks dan gambar terkait dalam petunjuk praktikum yang akan dibuat.
Petunjuk praktikum yang telah jadi merupakan tahap awal dari desain petunjuk praktikum, yang tentunya ini memerlukan uji ahli dan uji siswa untuk mengetahui kelayakan desain petunjuk praktikum yang telah dibuat. Setelah petunjuk praktikum tersebut selesai dibuat maka perlu diuji kelayakan secara bertahap mulai melalui uji ahli dan uji siswa.

Berdasarkan hasil pengujian yang telah dilakukan, menyatakan bahwa petunjuk praktikum yang dikembangkan ini dapat dimanfaatkan dalam kegiatan praktikum untuk siswa SMA kelas XI semester genap. Petunjuk praktikum ini telah memenuhi syarat kelayakan kriteria dalam aspek materi sebesar $86,18 \%$ atau termasuk dalam kategori sangat baik, aspek tampilan petunjuk praktikum sebesar $87,99 \%$ atau termasuk dalam ketegori sangat baik dan aspek interpretasi terhadap pendekatan ilmiah (scientifc approach) sebesar $85,32 \%$ atau termasuk dalam kategori sangat baik. Sementara rata-rata ketiganya sebesar $86,49 \%$ dengan kategori sangat baik. Sehingga menurut teori bahwa penelitian pengembangan petunjuk praktikum berbasis pendekatan ilmiah (scientific approach) adalah berhasil. Maka petunjuk praktikum ini layak untuk dijadikan penuntun dalam kegiatan praktikum.

Langkah selanjutnya adalah pengujian lapangan berdasarkan tanggapan/respon siswa untuk mengetahui tingkat kelayakan petunjuk praktikum berdasarkan pendapat siswa di sekolah. Pengujian di lakukan dengan cara praktikum di laboratorium dengan menggunakan petunjuk praktikum, kemudian setelah kegiatan praktikum selesai siswa memberikan pendapat melalui angket tanggapan/respon siswa. 
Praktikum ini dilakukan didua sekolah yaitu SMA N 6 Metro dan SMA Muhammadiyah 1 Metro. Persentase rata-rata hasil angket tanggapan/respon siswa di SMA N 6 Metro sebesar $87,11 \%$ dengan kategori sangat baik. Sedangkan hasil uji coba ke siswa SMA Muhammadiyah 1 Metro didapatkan hasil persentase rata-rata hasil angket tanggapan/respon siswa di SMA Muhammadiyah 1 Metro sebesar $85,71 \%$ dengan kategori sangat baik. Berdasarkan teori bahwa hasil analisis angket tanggapan/respon siswa di SMA N 6 Metro menghasilkan persentase rata-rata sebesar $87,11 \%$ dan di SMA Muhammadiyah 1 Metro menghasilkan persentase rata-rata sebesar $85,71 \%$ dan tergolong dalam kategori sangat baik. Sehingga penelitian ini dikatakan berhasil dimana petunjuk praktikum berbasis pendekatan ilmiah (scientific approach) layak untuk dijadikan penuntun dalam kegiatan praktikum.

\section{KESIMPULAN}

Dari data dan pembahasan dapat disimpulkan bahwa petunjuk praktikum yang dikembangkan mendapat respon positif dari ahli dan siswa. Petunjuk praktikum dapat membantu siswa dalam kegiatan praktikum.

\section{SARAN}

Beberapa saran yang dapat diberikan dalam pengembangan petunjuk diharapkan bisa dimanfaatkan sebagai penuntun yang dapat membantu dalam kegiatan praktikum. Pengembangan petunjuk praktikum ini bisa dilanjutkan dengan mencari pengaruhnya terhadap keterampilan psikomotor dan hasil belajar siswa dalam penggunaan petunjuk praktikum yang telah dikembangkan tersebut.

\section{DAFTAR RUJUKAN}

Kemdikbud. 2013. Diklat Guru dalam Rangka Implementasi Kurikulum 2013. Jakarta:

Farikhayati. 2009. Pengembangan Buku Petunjuk Kimia untuk SMP/MTS Kelas VII Berdasarkan Kurikulum Tingkat Satuan Pendidikan (KTSP). Skripsi diterbitkan. Yogyakarta:Program Studi Pendidikan Kimia Fakultas Sains Dan Teknologi Universitas Islam Negeri Sunan Kalijaga.

Kristiningrum. 2007. Pengembangan Multimedia Pembelajaran Interaktif dengan Macromedia Authorwere 7.0 pada Materi Fisika Sekolah Menengah Atas (SMA) Pokok Bahasan Kinematika Gerak Lurus. Skripsi diterbitkan. Semarang: Unnes.

Purnamasari, Shinta. 2012. Pengembangan Petunjuk Praktikum Kimia SMA Pada Pokok Bahasan Stoikiometri. Skripsi diterbitkan. Jakarta: UPI.

Santrock, W John. 2003. Adolescence Perkembangan Remaja. Jakarta: Erlangga.

Tim Penyusun Ilmu Pendidikan FIPUPI. 2007. Ilmu \& Aplikasi Pendidikan. Bandung: PT Imtina.

Trianto. 2011. Model Pembelajaran Terpadu. Jakarta: Bumi Aksara. 